\title{
Přikázání lásky k bližnímu v Jakubově listě Július Pavelčík
}

\begin{abstract}
Abstrakt
Starozákonní přikázání lásky k bližnímu (Lv 19,18) má nesporné výsadní postavení mezi ostatními přikázáními nejen v Ježíšově učení, ale i v Pavlových etických výzvách a také v Jakubově listě. Různé kontexty, v nichž se v jednotlivých novozákonních spisech nachází, svým specifickým způsobem akcentují jeho mimořádnou důležitost v životě raněkřestanských společenství. Tato studie se věnuje interpretaci přikázání lásky k bližnímu v Jakubově listě $(2,8)$, jehož specifické pojetí je zásadním způsobem podmíněno jak kontextovými souvislostmi, tak terminologií a frázemi, kterými je obklopeno a se kterými jsou spojeny různé interpretační těžkosti jazykového, sémantického a teologického charakteru. Láska k bližnímu je zde představena jako norma, která židokřest’anským adresátům listu poskytuje orientaci při rozhodování ohledně praktického uskutečňování jednotlivých požadavků Tóry v kontextu víry v Pána Ježíše Krista.
\end{abstract}

Klíčová slova: Jakubův list, zákon, přikázání, láska, bližní

\section{Úvod}

Přikázání lásky k bližnímu z Lv 19,18 se v Novém zákoně nachází 8krát (Mt 5,43; 19,19; 22,39; Mk 12,31.33; L 10,27; Ř 13,9; Ga 5,14; Jk 2,8), čímž je nejčastěji přímo citovaným starozákonním textem v Novém zákoně. Na všech místech je uvedeno ve spojitosti se Zákonem ${ }^{1}$ nebo jinými přikázáními Desatera. ${ }^{2}$ Různé souvislosti u synoptiků, u Pavla a Jakuba svým specifickým způsobem potvrzují a vyzdvihují jeho nespornou a zcela mimořádnou důležitost v životě raněkřest’anských společenství, zvlášt pro jejich reflexe způsobu dodržování starozákonních příkazů a zákazů v kontextu víry v Ježíše Krista, Božího Syna a Mesiáše.

V této studii nás zajímá způsob prezentace tohoto přikázání v Jakubově listě, proto bude pozornost nejdříve věnována jeho kontextuálnímu zasazení v rámci perikopy $2,1-13$, jejímž obsahem je stranění bohatým (vv. 1-7) propojené s tématem zákona (vv. 8-13), a také dalším kontextovým souvislostem $\mathrm{v}$ rámci listu. $\mathrm{V}$ dalších částech budou pojednány jednotlivé segmenty osmého verše druhé kapitoly, se kterými jsou spojené různé interpretační těžkosti jazykového, sémantického a teologického charakteru. Jejich objasnění nám umožní vytvořit si představu

\footnotetext{
V této studii se termín „Zákon“ používá jako ekvivalent Tóry a termín „zákon“ jako označení jakubovského pojetí této veličiny.

2 Srov. Pierre KEITH, La citation de Lv 19,18b en Jc 2,1-13, in: The Catholic Epistles and the Tradition, ed. Jacques SCHLOSSER, Leuven: Peeters, 2004, s. 234.
} 
o postavení přikázání lásky k bližnímu v prostředí židokřest’anského společenství, kterému je Jakubův list adresován.

\section{Text a překlad}

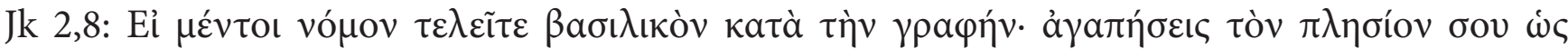

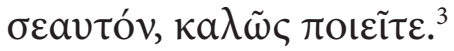

„Jestliže skutečně naplňujete královský zákon podle Písma: ,Milovat budeš svého bližního jako sebe samého,' dobře činíte." ${ }^{4}$

\section{Kontext}

Přikázání lásky k bližnímu je součástí širší textové jednotky Jk 2,1-13, o jejímž vymezení existuje v odborné literatuře vcelku zásadní shoda, přičemž se obvykle dále člení na dvě vzájemně propojené základní části: 2,1-7 a 2,8-13. Ačkoli je v 2,1-13 na první pohled výrazná prrítomnost „zákona“, přece jen je jemu nadřazeným tématem jisté patřičné jednání, které odpovídá víře v Pána Ježíše Krista (srov. 2,1). ${ }^{5}$

Veršům 8-13 zcela jednoznačně dominuje téma zákona, což je dáno především pěti z celkem deseti výskytů slova vó $\mu \mathrm{o} \varsigma \mathrm{v}$ Jakubově listě $(1,25 ; 2,8.9 .10 .11 .12 ; 4,11$ [4krát]). Př́má citace př́ikázání lásky spolu se dvěma citovanými přikázáními, přesněji zákazy z Desatera ve v. 11, dávají specifický ráz skupině veršů 8-11, které lze na základě slovní zásoby a syntaxe ${ }^{6}$ snadno odlišit od jejich bezprostředního kontextu. ${ }^{7}$

Žádné z citovaných přikázání svým obsahem neodpovídá přímo autorově výtce o nadržování osobám $\mathrm{z}$ úvodního verše druhé kapitoly. ${ }^{8}$ Zatímco ve vv. 1-7 vystupuje do popředí kontrast mezi bohatým a chudým, resp. mezi projevením úcty a projevením neúcty vưči nim, verše $8-11$ jsou vystavěny na kontrastu mezi tím, kdo zákon zachovává, a tím, kdo ho přestupuje (vó $\mu$ ov $\tau \varepsilon \lambda \varepsilon i ̃ \tau \varepsilon$

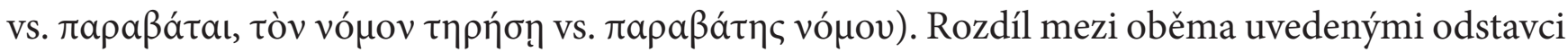
je také ve stylu: rétorické otázky ve vv. $4-7^{9}$ obracející se přímo na adresáty (ve 2. os. pl.) jsou ve vv. 8-11 vystřídány argumentací formou podmínkových souvětí (v nichž se střídá 2. os. pl. a 3. os. sg.) propojených kauzálními spojkami. ${ }^{10}$ Konkrétní smýšlení a jednání charakteristická pro skupinu adresovaných osob jsou vystř́ídána obecnějšími ${ }^{11}$ konstatováními morálního charakteru založenými na normách Zákona obsaženého v Písmu Starého zákona. ${ }^{12}$ Verše $1-7$ vyjadřují negativní

3 Řecký text Nového zákona je převzatý z Novum Testamentum Graece, 28. vyd., ed. Barbara ALAND et al., Stuttgart: Deutsche Bibelgesellschaft, 2012; řecký text Starého zákona ze Septuaginta: Id est Vetus Testamentum graece iuxta LXX interpretes, ed. Alfred RAHLFS, duo volumina in uno, Stuttgart: Deutsche Bibelgesellschaft, 1979.

4 Veškeré překlady řeckého biblického textu pro potřeby této studie jsou mé vlastní.

5 Na to ukazuje doširoka rozvedené téma nežádoucího nadržování osobám ve vv. 1-7 a také jednání popisovaná ve vv. 8-13 různými

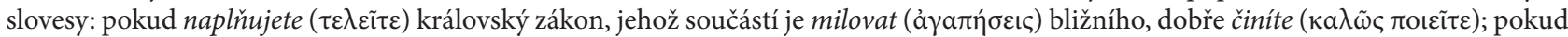

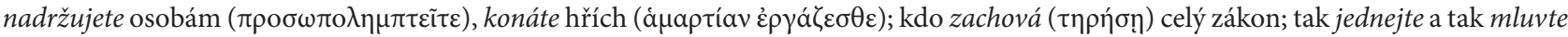

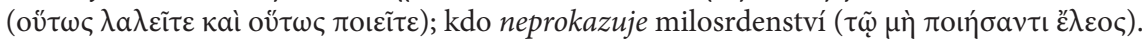

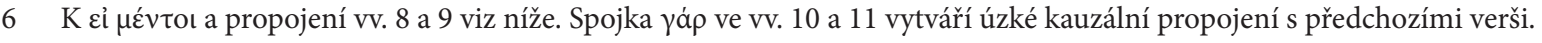

7 Srov. KEITH, La citation..., s. 241.

8 Srov. KEITH, La citation..., s. 241.

9 V. 4 je gramaticky apodosis rozsáhlého podmínkového souvětí, jehož protasis zahrnuje vv. 2-3.

10 Rainer METZNER, Der Brief des Jakobus, Leipzig: Evangelische Verlagsanstalt, 2017, s. 126-127: „8 öffnet um den Begriff vó $\mu$ oৎ (...) kreisenden Gedankengang, der nicht mehr fragend, sondern lehrend argumentiert (erste Schriftzitate 2,8.11).“

11 Christoph BURCHARD, Nächstenliebegebot, Dekalog und Gesetz in Jak 2,8-11, in: Die Hebräische Bibel und ihre zweifache Nachgeschichte (FS R. Rendtorff), ed. Erhard BLUM - Christian MACHOLZ - Ekkehard W. STEGEMANN, Neukirchen-Vluyn, 1990, s. 525: „Tatsächlich besprechen V. 8ff. wohl nicht mehr das Beispiel, sondern greifen das allgemeine Verbot V. 1 wieder auf.“

12 Luke L. CHEUNG, The Genre, Composition and Hermeneutics of James, Carlisle, Cumbria, U. K.: Paternoster Press, 2003, s. 97: „Our author 
aspekt kritiky adresátů, protože jsou namířeny proti špatnému postoji stranění společenství, který je neslučitelný s jejich vírou v Ježíše Krista. Ve verši 8 autor formuluje pozitivní stránku své náboženské argumentace, když jim jako alternativu předkládá realizování „královského zákona podle Písma" způsobem odpovídajícím přikázání lásky $\mathrm{k}$ bližnímu, ${ }^{13} \mathrm{~s}$ nímž je kritizované nadržování bohatým osobám neslučitelné. Ve vv. 9-10 je toto stranění dále představeno jako hříšné jednání

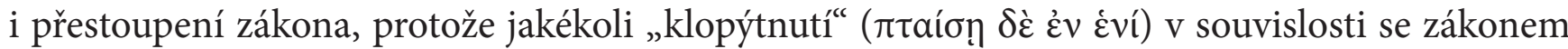

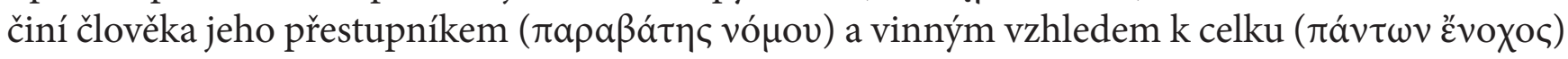
toho zákona, podle kterého budou adresáti nakonec souzeni (v. 12). Pro úplnost je třeba dodat, že postoj společenství jak vưči bohatým, tak i chudým je podle autora také v přímém rozporu nejen s postojem samotného Boha (v. 5-6a), ale současně i s jejich vlastní zkušeností s bohatými lidmi. Právě oni mají podle popisu ve vv. 2,6b-7 k adresátům pouze negativní postoj, utlačují je, tahají po soudech a hanobí dobré jméno, které bylo nad nimi vzýváno. ${ }^{14}$

Nelze přirozeně opomenout důležité propojení obou částí prostřednictvím termínů vyjadřujících

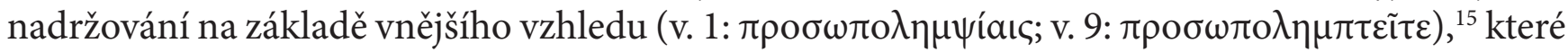
nešetři projevy pocty některým osobám a odpírá je jiným z důvodů, které nemají nic společné s jejich skutečnou zásluhou a zároveň odporují víře v Ježíše Krista (v. 1). Adresáti listu zneuctují

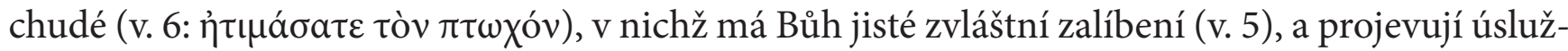
nost bohatým (v. 3). Téma stranění je ve vv. 8-11 explicitně propojeno s tématem zákona. ${ }^{16}$

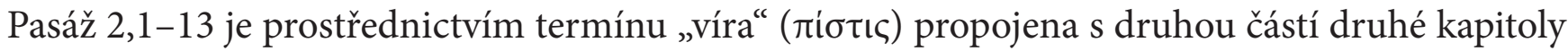

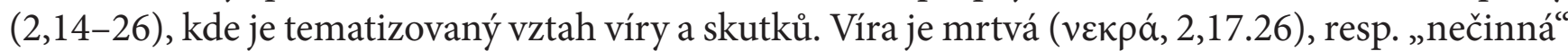

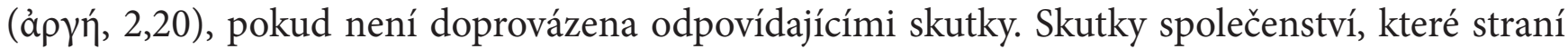
bohatým, tak neodpovídají jeho víře ani přikázání lásky k bližnímu, které je rozhodujícím ukazatelem náležitého chování ve shodě s proklamovanou vírou. ${ }^{17}$

S bezprostředně předcházejícím textem (1,26-27) jsou verše 2,1-13 propojeny prostřednictvím termínu kó $\mu$ oc, s nímž je spojen nesmiřitelný kontrast mezi Bohem a světem ${ }^{18}$ týkající se uskutečňování autentické nábožnosti $(1,27)$, resp. správného postoje vưči chudým $(2,5)$ jak v životě jednotlivce, tak i v životě společenství. Na základě této souvislosti pak lze téma nadržování bohatým a znevažování chudých coby projevy mentality „světa“ uvést do vztahu s péčí o vdovy a siroty $(1,27) .{ }^{19}$ Obojí vyzvedá a potvrzuje silný důraz autora listu na sociální aspekty života společenství a jeho zájem o ně (viz také $2,15-17 ; 5,4) .^{20}$

is here setting off a scriptural argument against the practise of favouritism. "Wiard POPKES, Der Brief des Jakobus, Leipzig: Evangelische Verlagsanstalt, 2001, s. 154: „Der Abschnitt V. 8-13 ist somit viel grundsätzlicher, sozusagen bibeldogmatischer gehalten als der vorige.“

13 Srov. Ingeborg MONGSTAD-KVAMMEN, Toward a Postcolonial Reading of the Epistle of James: James 2:1-13 in its Roman Imperial Context, Leiden/Boston: Brill, 2013, s. 177.

14 METZNER, Brief..., s. 109-110: „Der Verzicht auf parteiisches Verhalten wird in 2,2-4 an einem Beispiel erläutert und anschließend theologisch begründet: Bevorzugung der Reichen widerspricht der göttlichen Erwählung der Armen (2,5-7 fragender Teil), dem Gebot der Nächstenliebe (2,8-11 lehrhafter Teil) und der Barmherzigkeit, deren Unterlassen ein erbarmungsloses Gericht nach sich zieht (2,12-13 mahnender Teil).“

15 K překladu těchto termínů viz Ladislav TICHÝ, Slovník novozákonní řečtiny, Olomouc: Burget, 2001, s. 148; Helena PANCZOVÁ, Grécko-slovenský slovník od Homéra po krestanských autorov, Bratislava: Lingea, 2012, s. 1069.

16 METZNER, Brief..., s. 126-127: „Das Thema 'Parteilichkeit' wird nicht verlassen, sondern mit dem Gesetz in Beziehung gesetzt: Nächstenliebe verbietet Ungleichbehandlung."

17 Srov. MONGSTAD-KVAMMEN, Toward..., s. 178.

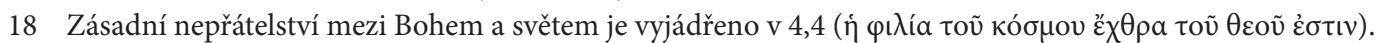

19 METZNER, Brief..., s. 110: „Wenn Jakobus vor einer die 'Armen' verachtenden Parteilichkeit warnt, nachdem es sich für 'Waisen und Witwen' eingesetzt hat, dann nimmt er einen traditionellen Zusammenhang auf." Gerhard MAIER, Der Brief des Jakobus, Witten: SCM R. Brockhaus; Giessen: Brunnen Verlag, 2. Auflage, 2009, s. 105: „Die Fürsorge für die Schwache bildete schon ein Thema für 1,26-27, jetzt setzt es sich in Ehrung und Barmherzigkeit gegenüber den Armen fort.“

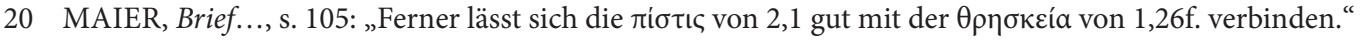




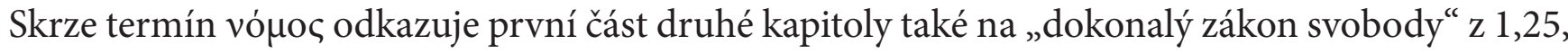
kde se o něm mluví ve spojitosti $\mathrm{s}$ tématem naslouchání a mluvení. Autor $\mathrm{v}$ této části apeluje na adresáty, aby nebyli pouze pasivními př́ijemci slova, nýbrž i jeho aktivními vykonavateli (1,19-25). Oddíl 2,8-11 je $\mathrm{v}$ této souvislosti důležitý také $\mathrm{z}$ toho důvodu, že upřesňuje obsah „zákona“ ${ }^{21}$ Pro celkové pochopení „zákona“ v Jakubově listě jsou následně velmi důležité verše 4,11-12, které kromě odsouzení vzájemného pomlouvání jasně identifikují Boha jako „jediného Zákonodárce a Soudce“.

\section{Verše 2,8 a 2,9}

Jistou zvláštní pozornost zasluhuje vzájemný vztah veršů 8 a 9, které vykazují propojení na několika úrovních. Z hlediska syntaktického to jsou dvě podmínková souvětí spojená prostřednic-

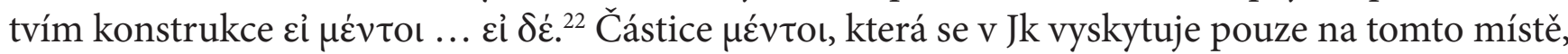
může mít dva základní významy, totiž (1) afirmativní, potvrzující: „skutečně, vskutku, zajisté“ a (2) adverzativní, odporující: „však, avšak, ale, nicméně přesto“ ${ }^{23}$ Níže uvedená interpretace vztahu veršu 8 a 9 podporuje použití této částice ve v. $8 \mathrm{v}$ prvním významu, ačkoli na všech ostatních místech v Novém zákoně se zdá mít spíše význam adverzativní. ${ }^{24}$ Ve významu „skutečně“ se pak vztahuje $\mathrm{k}$ tomu, co následuje a vytvář́ přechod k pod-oddílu vv. 8-11..$^{25}$

Verše 8 a 9 obsahují inkluzi vytvořenou termínem „zákon“, který na začátku 8. verše stojí jako normativní veličina jednání a na konci 9. verše jako veličina soudní, která usvědčuje z hříchu. Obsah této inkluze v uvedených verších tvoří antitetický paralelismus ${ }^{26} \mathrm{kdy}$ ve vzájemné opozici

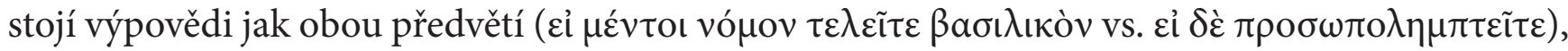

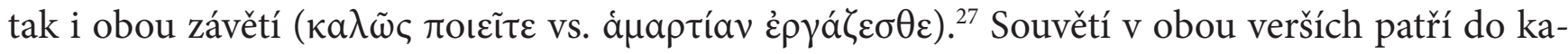
tegorie reálných podmínkových souvětí, jejichž vztah (prostřednictvím protasis) k realitě je sám o sobě neurčitý; vyjadřují pouze tu skutečnost, že vztah mezi předvětím a závětím v nich je skutečný, resp. logicky nutný. ${ }^{28}$ To ovšem ponechává otevřené, jaký je skutečný status quo ve společenství v projednávané otázce. ${ }^{29}$ Je velmi pravděpodobné, že v. 9a odkazuje na skutečný, ne pouze fiktivní nebo hypotetický př́pad (případy?) stranění bohatým popsaný ve vv. $2-4 .{ }^{30} \mathrm{Z}$ toho

21 KEITH, La citation..., s. 232: „C’est aussi le seul passage de lépître dans lequel l’auteur identifie des commandements qui appartiennent à cette Loi.“

22 Luke Timothy JOHNSON, The Use of Leviticus 19 in the Letter of James, Journal of Biblical Literature 3/1982, s. 400: „Unquestionably, the $\mu \dot{\varepsilon} v \tau$ To of v. 8 and the $\delta \dot{\varepsilon}$ of v. 9 must be seen as correlative."

23 Srov. TICHÝ, Slovník..., s. 109; PANCZOVÁ, Slovník..., s. 808.

24 Srov. Dale C. ALLISON, A Critical and Exegetical Commentary on the Epistle of James, New York/London/New Delhi/Sydney: Bloomsbury, 2013, s. 401.

25 Srov. I-Jin LOH, Howard A. HATTON, A Handbook on the Letter from James, New York: United Bible Societies, 1997, s. 72; Rinaldo FABRIS, Legge della libertà in Giacomo, Brescia: Paideia, 1977, s. 67, pozn. 55.

26 Srov. MONGSTAD-KVAMMEN, Toward..., s. 178; Franz MUSSNER, Der Jakobusbrief, Fünfte, durchgesehene Auflage, Freiburg/ Basel/Wien: Herder, 1987, s. 123; Douglas J. MOO, James: An Introduction and Commentary, Downers Grove, Illinois: IVP Academic; Nottingham, England: Inter-Varsity Press, 2007, s. 95.

27 Srov. KEITH, La citation..., s. 242-243.

28 Srov. Heinrich von SIEBENTHAL, Griechische Grammatik zum Neuen Testament, Neubearbeitung und Erweiterung der Grammatik Hoffmann / von Siebenthal, Gießen und Basel: Brunnen, Basel: Immanuel, s. 201, par. 280c a 281; Friedrich BLASS - Albert DEBRUNNER - Friedrich REHKOPF, Grammatik des neutestamentlichen Griechisch, 17. Auflage, Göttingen: Vandenhoeck \& Ruprecht, 1990, par. 371, pozn. 1.

29 Její zodpovězení docela zásadním způsobem ovlivňuje výklad, a proto ji nakonec nelze bagatelizovat, jak by se snad mohlo usuzovat např. na základě tvrzení MONGSTAD-KVAMMEN, Toward..., s. 179: „However, whether the conditional sentences here are linked to real life or not, is actually not the most important aspect. The most important aspect is that the sentences in effect are saying this: a. Love your neighbour as yourself. b. Do not show partiality."

30 Tak např. ALLISON, Commentary..., s. 377: „One doubts, however, that our text is only hypothetical. If an example is foreign to the readers' experience, its force diminished (...).“ 
lze usuzovat, ${ }^{31}$ vezmeme-li zároveň v potaz kontrastní charakter obou veršů, že i v. 8a popisuje realitu, tedy že oslovené společenství nějakým způsobem naplňuje, resp. je schopné naplňovat královský zákon podle přikázání lásky k bližnímu. Adresáti na jedné straně svým nadržováním bohatým sice přestupují zákon, na druhé straně jsou však schopni konat dobro, jestliže nějakým jiným způsobem projevují lásku svým bližním. ${ }^{32}$ Tato diskrepance čtenáře listu nepřekvapuje, protože je v podstatě jen jedním z projevů rozpolcenosti v jednání společenství, který je zásadně spojený s jeho rozpolceným vztahem k Bohu. „Společenství v Jakubově listě je rozpolcené, protože není schopné se plně podřídit Bohu, Boží vưli. Žije životem plným kompromisu se ,světem; s jeho uvažováním, hodnotami a normami (srov. 2,1-13; 4,1-3.13-16). “33 Obě popisovaná jednání se tak na základě této úvahy vzájemně nevylučují, a proto lze souhlasit s názorem (1), který dvě podmínky interpretuje jako současné v tom smyslu, že ti, kdo milují bližního, zároveň nadržují bohatým. Podle této interpretace autor listu říká, že adresáti, i když jinak jsou nějakým zpơsobem schopni projevovat lásku svým bližním, ${ }^{34}$ jestliže straní bohatým, jsou přestupníky zákona

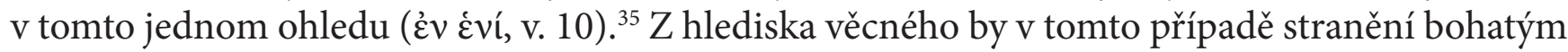
bylo vnímáno spíš jako přestoupení zákazu formulovaného v Lv 19,15, na který zřejmě naráží v. $9 .{ }^{36}$ Ačkoli přikázání lásky má jisté výsadnější postavení vzhledem k ostatním přikázáním, není ani ve v. 8, ani nikde v Jakubově listě identifikováno se „zákonem“. Proto se také jeví jako méně přesvědčivý - jinak většinový - názor (2), který podmínková souvětí ve verších 8 a 9 interpretuje jako protikladná ${ }^{37} \mathrm{v}$ tom smyslu, že ti, kdo straní bohatým, tímto svým jednáním přestupují právě a především přikázání lásky $\mathrm{k}$ bližnímu. ${ }^{38}$ Toto upřesnění („především“) zde hraje důležitou roli; první, zde zastávaný názor neimplikuje, že by se adresáti svým chováním k bohatým (a chudým) neprohřešovali proti lásce k bližnímu; proviňují se tím proti „zákonu“, věcně a na prvním místě proti zákazu stranění (Lv 19,15), ${ }^{39}$ a tím také proti lásce k bližnímu. ${ }^{40}$ Samotné přikázání lásky je obsahově velmi široké, následně k němu coby vůdčímu nebo sumarizujícímu principu lze vztahovat nějakým způsobem všechny předpisy týkající se (uspořádání) mezilidských vztahů. ${ }^{41}$ Jako další argument ve prospěch výše zmíněného názoru (1) lze uvést jistou podobnost mezi verši

31 Podle mnoha jiných autorů však pouze v. 9 je odrazem reality a v. 8 je čistě hypotetický. ALLISON, Commentary..., s. 401, pozn. 221: „This is the view of most commentators, who see partiality as contradicting love of neighbor.“

32 Srov. MONGSTAD-KVAMMEN, Toward..., s. 178-179.

33 Blažej ŠTRBA a kol., Emócie v Biblii. Výskum fenoménu emócií v biblickej tradícii, Bratislava: RKCMBF UK, 2018, s. 264. Více ke vztahu adresátů k „světu“ viz Július PAVELČÍK, Nábožnost’ podla Jak 1,27, Studia theologica 2/2019, s. 19-42.

34 Srov. Matt A. JACKSON-MCCABE, Logos and Law in the Letter of James. The Law of Nature, the Law of Moses and the Law of Freedom, Leiden; Boston; Köln: Brill, 2001, s. 168-169; KEITH, La citation..., s. 243.

35 Gerd THEISSEN, Nächstenliebe und Egalität. Jak 2,1-13 als Höhepunkt urchristlicher Ethik, in: Petra v. GEMÜNDEN - Matthias KONRADT - Gerd THEISSEN, Der Jakobusbrief. Beiträge zur Rehabilitierung der „strohernen Epistel“, Münster: LIT, 2003, s. 128: „Der

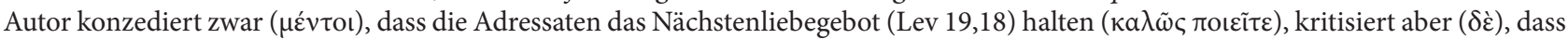
sie gegen das Gleichheitsgebot (Lev 19,15) verstoßen - um dann nachzuweisen, dass sie mit dem Bruch des einen Gebots das ganze Gesetz (und damit auch das Liebesgebot) verletzen."

36 Srov. KEITH, La citation..., s. 243.

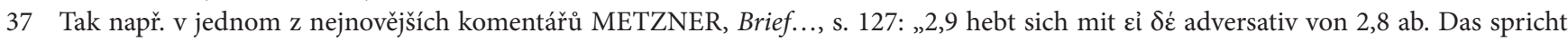

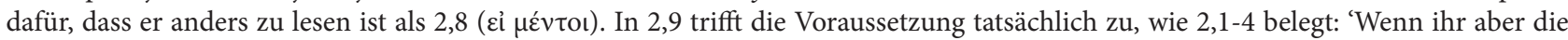
Person anseht (was der Fall ist), tut ihr Sünde. In 2,8 ist die Lage anders, denn Jakobus wird nach der bisherigen Kritik an liebloser Parteilichkeit nicht zugestehen wollen, dass die Adressaten den Nächsten lieben und so das Gesetz erfüllen. Daher ist عỉ $\mu \varepsilon ́ v \tau o t ~ n i c h t$ konfirmativ ( $\mu \varepsilon \dot{\varepsilon} v$-confirmativum) gemeint ('Wenn ihr in der Tat das königliche Gesetz erfüllt usw.), sondern zweifelnd-konzessiv: 'Wenn ihr jedoch das königliche Gesetz erfüllt (was nicht der Fall ist) usw., tut ihr gut'. 2,9 sagt, wie es ist, 2,8 wie es sein sollte."

38 V tomto př́padě je přikázání lásky představeno podle KEITH, La citation..., s. 243 jako „'unique commandement souverain de 'la Loi royale"“

39 Viz níže, s. 152

40 Srov. THEISSEN, Nächstenliebe..., s. 127-128.

41 Matthias KONRADT, The Love Command in Matthew, James, and Didache, in: Matthew, James, and Didache: Three Related Documents in TheirJewish and Christian Settings, ed. Huub van de SANDT - Jürgen K. ZANGENBERG, Atlanta: Society of Biblical Literature, 2008, s. 279: "the love command formulates the basic intention or nature of the law, which is then explicated by other regulations." 
8-9 a 10 a 11. Podle v. 9b jsou totiž ti, kdo straní bohatým, usvědčeni „zákonem“42 jako jeho pře-

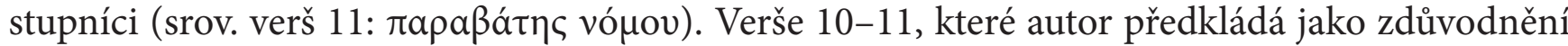
tvrzení nebo spíše obvinění ve v. 9, pak obsahují jistou variaci výše zmíněné diskrepance, resp. nedůslednosti z veršů 8-9 (chápaných jako současné podmínky) ${ }^{43}$. Podobný myšlenkový duktus v uvedených verších ${ }^{44}$ lze př̀iblížit následovně:

(A) vv. 8-9: stranění (bohatým) je přestoupením zákona, ačkoli člověk jinak žije podle jeho normativní směrnice, totiž přikázání lásky k bližnímu. ${ }^{45}$

(B) v. 10: provinění vưči zákonu v jednom ohledu činí člověka vinným i ve všech ostatních, ačkoli jinak ostatní části zákona zachovává. ${ }^{46}$

(C) v. 11:47 člověk, který vraždí, přestupuje zákon, ačkoli necizoloží, tedy v jiném ohledu ho dodržuje.

Stranění bohatým, zde spojené se zneuctěním chudých, ačkoli patřilo k „dobrým mravům“ v tehdejší římské společnosti a bylo součástí její etikety, je pro autora listu nepřijatelné, není totiž pro něho otázkou etikety, ale zákona. „Život podle římské etikety z vás automaticky činí hříšníky podle Božího zákona, protože římská společnost je postavená na stranění. Co je přijatelné v římské společnosti, je nepřijatelné podle Božího zákona. Rímská etiketa stranění je urážkou Boha a přestoupením přikázání lásky. " ${ }^{88}$ Stranění osobám ( $\left.\pi \rho \circ \sigma \omega \pi \circ \lambda \eta \mu \psi i a\right)$ jako úvodní téma druhé kapitoly je přestoupením zákona (srov. 2,9.10) v několika ohledech: není totiž jen porušením zákazu nadržování osobám (Lv 19,15), ale také prohřeškem proti přikázání lásky k bližnímu a proviněním se vưči celému královskému zákonu.

\section{Naplňovat královský zákon}

„Zákon“ (vófoc: 1,25; 2,8.9.10.11.12; 4,11[4krát]) je zcela nesporně jedním z teologicky nejrelevantnějších termínů Jakubova listu. ${ }^{49}$ Pojednává se o něm ve třech různých kontextech vždy v souvislosti s jistým jednáním: ${ }^{50}$ zákon a praktické realizování slova $(1,22-27)$, zákon a nadržování osobám $(2,1-13)$, zákon a osočování $(4,11-12) .{ }^{51}$ Ve čtyřech prrípadech je opatřen různými atributy: „dokonalý zákon svobody“ (1,25); „královský zákon“ $(2,8)$; „celý zákon“ $(2,10)$, „zákon svobody“ $(2,12)$. Tato bližší určení označují tři různé aspekty jednoho a téhož zákona a společně

42 Určitý člen zde neodkazuje na přikázání lásky z v. 8, ale na „královský zákon“. Viz THEISSEN, Nächstenliebe..., s. 128.

43 JACKSON-MCCABE, $\operatorname{Logos} . .$. , s. 171: „The correspondences between the two conditional statements of 2:8-9 and the complex conditions of 2:10 and 2:11 are in fact quite striking."

44 Srov. JACKSON-MCCABE, Logos..., s. 169-176; KEITH, La citation..., s. 243-244.

45 JACKSON-MCCABE, Logos..., s. 174: „Regardless of its possible summarizing function, 'loving one's neighbor as oneself' is not, without further ado, simply equivalent to fulfilling the whole law in the Letter of James."

46 BURCHARD, Nächstenliebegebot..., s. 527-528: „Dies (...), weil man die Autorität des ganzen Gesetzes bestreitet, wenn man ein Stück

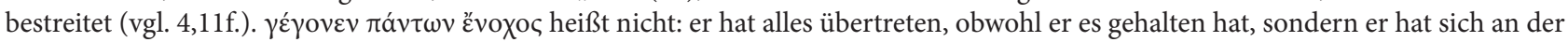
Würde des ganzen Gesetzes versündigt (vgl. 1 Kor 11,27).“

47 V této souvislosti lze tento verš chápat jako názorný př́klad myšlenky z předchozího verše. Viz také KEITH, La citation..., s. 244.

48 MONGSTAD-KVAMMEN, Toward..., s. 189.

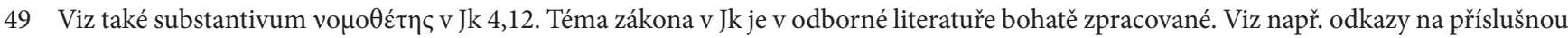
literaturu v Július PAVELČÍK, „Dokonalý zákon slobody“ (Jak 1,25). K chápaniu zákona v Jakubovom liste, Studia Biblica Slovaca 2/2011, s. 175, pozn. 14, 15 a 16. V následující části se omezíme pouze na ty aspekty zákona, které jsou relevantní pro interpretaci vztahu „královského zákona“ a přikázání lásky k bližnímu.

50 William F. BROSEND, James and Jude, Cambridge: Cambridge University Press, 2004, s. 69: „'Law, above all, is what members of the community are to 'do."

51 BROSEND, James..., s. 68: „In each case, James's use of law is subordinate - in support of - a point he is trying to make.“ 
vytvářejí jeho specifické jakubovské pojetí. ${ }^{52}$ „Zákon“ v Jakubově listě lze v jistém ohledu ztotožnit se "slovem“ (srov. 1,18.21.22-25), ${ }^{53}$ vyjadřuje totiž jeho imperativní, normativní a zavazující charakter, ${ }^{54}$ proto „dokonalý zákon svobody“ (v. 25: vó redukován pouze na jeden požadavek zákona. ${ }^{55}$ To také potvrzuje verš 2,10 , kde je prostřednic-

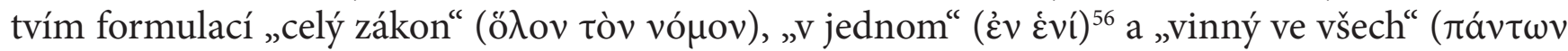

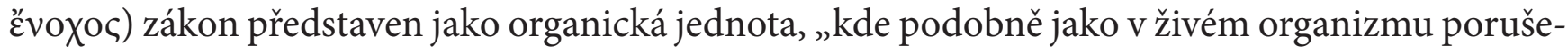
ní jednoho místa narušuje rovnováhu celého organizmu“" ${ }^{57}$ Zákon jako samostatná veličina si tím, že „usvědčuje“, nárokuje jistou autoritu, jedná jako soudce a je téměř personifikovaný ${ }^{58}$ Garantem autority a organické celistvosti zákona a jeho jednotlivých částí59 je nakonec sám Bůh jako jeho jediný Zákonodárce $(4,12){ }^{60}$

V souvislosti s charakteristikou zákona „královský“ ( $\beta a \sigma \iota \lambda \iota k o ́ \varsigma)$, jedinečnou v celém Novém zákoně, ${ }^{61}$ lze uvažovat o několika možnostech její interpretace: ${ }^{62}$

(1) Ukazuje na to, že zákon pochází od krále, je to zákon vydaný samotným králem.

(2) Souvisí s „královstvím“ uvedeným ve v. 5, je to zákon související s tímto královstvím, které je přislíbeno těm, kdo milují Boha.

(3) Charakterizuje královské, prominentní postavení přikázání lásky k bližnímu vzhledem k ostatním přikázáním.

(4) Na rozdíl od předchozího, královský charakter nemá pouze jedno přikázání, ale celý zákon, a to na základě své funkce či svého postavení.

(5) Vztahuje se na adresáty zákona, kteří se jeho plněním stanou samotnými králi, nejen dědici, resp. obyvateli království.

(6) Různé kombinace předchozích interpretací.

Ačkoli tř̌etí intepretace, identifikující „královský zákon“ s přikázáním lásky k bližnímu, se zdá být většinová, ${ }^{63}$ lze ji považovat za nejméně pravděpodobnou především $\mathrm{z}$ toho důvodu, že na všech ostatních místech v Jakubově listě se „zákonem“ míní vždy celý zákon, ${ }^{64}$ který nelze redukovat na

52 Srov. MONGSTAD-KVAMMEN, Toward..., s. 179; PAVELČÍK, Zákon..., s. 175.

53 Viz podrobně PAVELČÍK, Zákon..., s. 176-185.

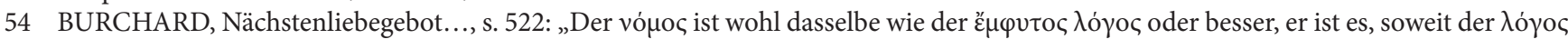
Taten fordert."

55 Srov. Rudolf HOPPE, Der theologische Hintergrund des Jakobusbriefes, Würzburg: Echter Verlag, 1977, s. 89.

56 Dativ Ėví je třeba chápat jako neutrum, které odkazuje na jeden aspekt, resp. na jednu část zákona. Srov. CHEUNG, Genre..., s. 121; HOPPE, Hintergrund..., s. 91; BURCHARD, Nächstenliebegebot..., s. 527-528.

57 PAVELČÍK, Zákon..., s. 206.

58 Srov. MONGSTAD-KVAMMEN, Toward..., s. 189; HOPPE, Hintergrund..., s. 90; Patrick J. HARTIN, James, Collegeville, Minnesota: Liturgical Press, 2003, s. 135.

59 MONGSTAD-KVAMMEN, Toward..., s. 192, pozn. 327: „The law is not only a series of individual commandments. The single commandments are all representative of the whole law."

60 Srov. CHEUNG, Genre..., s. 122; Stefan WENGER, Der wesenhaft gute Kyrios. Eine exegetische Studie über das Gottesbild im Jakobusbrief, Zürich: Theologischer Verlag, 2011, s. 152.

61 Srov. MAIER, Brief..., s. 116-117.

62 Viz přehledy různých dělení, kde jsou uvedené také odkazy na zastánce jednotlivých interpretací: např. THEISSEN, Nächstenliebe..., s. 132-134; WENGER, Kyrios..., s. 151; LOH - HATTON, A Handbook..., s. 72-73; ALLISON, Commentary ..., s. 403-404; Hubert MEISINGER, Liebesgebot und Altruismusforschung. Ein exegetischer Beitrag zum Dialog zwischen Theologie und Naturwissenschaft, Freiburg, Schweiz: Universitätsverlag; Göttingen: Vandenhoeck und Ruprecht, 1996, s. 137-138.

63 Podobně také české komentáře: František KOVÁ̌̌, Výklad listu Jakubova, Praha: Husova československá bohoslovecká fakulta, 1954, s. 37; František NOVÁK, List sv. Jakuba, Pardubice: nákladem vlastním, 1905, s. 37; Josef B. SOUČEK, Dělná víra a živá naděje. Výklad epištoly Jakubovy a první epištoly Petrovy, Praha: Kalich, 1968, s. 45; Jiří MRÁZEK, Bláznovství víry podle Jakuba: Výklad Jakubovy epištoly, Jihlava: Mlýn, 2006, s. 48-49.

64 Srov. THEISSEN, Nächstenliebe..., s. 133. 
jedno přikázání, jakkoli prominentnější než všechna další. Na druhé straně, i když ji nepřijmeme, nelze ani u zbývajících možností popřít jisté výsadnější postavení tohoto přikázání uvnitř zákona. ${ }^{65}$ Ostatní uvedené možnosti týkající se zákona jako celku se spíš vzájemně doplňují, ${ }^{66}$ než že by se navzájem vylučovaly, což může souviset s různými rovinami významu samotného adjektiva „královský“" 67 ponechaného autorem listu bez bližší specifikace. Proto lze formulovat charakteristiku „královského“ zákona ${ }^{68}$ např. tak, že je to zákon pocházející od Boha (srov. 4,12), Krále, má královskou důstojnost a autoritu a má platnost v jeho království. ${ }^{69}$ Atribut „královský“ v sobě v každém případě obsahuje představu nejvyššího postavení, nejvyšší hodnosti, ale také dokonalosti, čímž se přibližuje atributu zákona „dokonalý“ $(1,25)^{70}$ a „jasně zdůrazňuje důležitost zákona (vó $\mu$ os) a implikuje závazek zachovávat ho“.71

V souvislosti s přestoupením zákona jsou v 2,11 jako konkrétní příklady výslovně uvedena dvě přikázání z Desatera, a proto lze oprávněně usuzovat na to, že „zákon“ jako hlavní téma oddílu 2,8-13 zahrnuje Mojžíšův zákon, (celou) Tóru. ${ }^{72}$ Zákon jako celek $(2,10)$ je výrazem vůle jediného Boha, Zákonodárce $(4,12)$ a současně také normou křestanského ${ }^{73}$ jednání, která je konkrétně formulována v jednotlivých přikázáních Mojžíšova zákona (srov. 2,10.11) a eminentním způsobem v přikázání lásky k bližnímu (2,8), neoddělitelném od lásky k Bohu. Přikázání lásky k bližnímu (v. 8), které má jisté normativní postavení, ${ }^{74}$ a projevování milosrdenství, které je rozhodujícím faktorem u soudu (v. 13), rámují tematiku zákona ve druhé kapitole listu. Slouží proto „jako jisté hermeneutické principy pojetí zákona, výkladu zákona, jako ,kritická norma‘ vzhledem k Tóře. "75 Poskytují tak židokřestanskému společenství adresátů praktickou orientaci při rozhodování ohledně naplňování

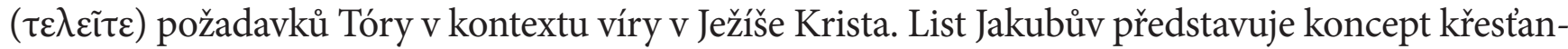
sky interpretované Tóry ${ }^{76}$ založený také na Ježíšově interpretaci Zákona. ${ }^{77}$

Sloveso $\tau \varepsilon \lambda \varepsilon \tilde{v} v$ se základním významem „dokončit“78 má ve spojení se „zákonem“ spíš význam „naplňovat zákon“ve smyslu „činit v plném rozsahu / v plné míře“ (srov. např. L 2,39). ${ }^{79} \mathrm{~V}$ popředí

65 Srov. MEISINGER, Liebesgebot..., s. 138; Sophie LAWS, A Commentary on the Epistle of James, London: Adam \& Charles Black, 1980 , s. 108.

66 Viz Wenger, Kyrios, 151; MEISINGER, Liebesgebot..., s. 138, pozn. 31; THEISSEN, Nächstenliebe..., s. 134.

67 Srov. ALLISON, Commentary..., s. 405; JACKSON-MCCABE, Logos..., s. 154.

68 Velmi výstižnou a hutnou charakteristiku podává WENGER, Kyrios..., s. 156: „Der vó wesenhaft guten König geschenkte, inhaltlich auf das Gesetz der Nächstenliebe fokussierte (aber nicht darauf reduzierte) vollkommene Wegweisung, die (Christen-)Menschen einerseits zu entsprechendem Leben gegenüber dem darin explizierten Willen ihres kúpıৎৎ verpflichtet und sie andererseits zum segensreichen Leben in Gottes Königreich freisetzt.“

69 Aplikace adjektiva „královský“ na adresáty, uvedená v páté možnosti, není sice zcela nepřijatelná, ale není ani zcela bezproblémová. CHEUNG, Genre..., s. 97: „it is hard to understand why it is necessary in our author's argument to describe the law as 'for the kings' here."

70 Srov. Ceslas SPICQ, Agapè dans le Nouveau Testament: analyse des textes I, Paris: J. Gabalda, 1958, s. 196.

71 ALLISON, Commentary..., s. 404.

72 K problematice „celého zákona“ (v. 10) viz podrobněji PAVELČÍK, Zákon..., s. 204-209.

73 O zákonu se v Jk mluví v kontextu „víry v našeho Pána Ježíše Krista“ (Jk 2,1).

74 CHEUNG, Genre..., s. 123: „Substantially, this whole law is not in any way different from the Mosaic law, but as to its significance and application, it is the royal law or the perfect law of liberty as summarised, interpreted and fulfilled through the love command."

75 PAVELČÍK, Zákon..., s. 203. KEITH, La citation..., s. 243: „le commandement de l’amour est un commandement important, mais non isolé. Son role correspondrait à celui d’un principe herméneutique, particulièrement adapté à la situation évoquées par l'auteur." Srov. Hubert FRANKEMÖLLE, Gesetz im Jakobusbrief. Zur Tradition, kontextuellen Verwendung und Rezeption eines belasteten Begriffes, in: Das Gesetz im Neuen testament, ed. Karl KERTELGE, Freiburg im Breisgau/Basel/Wien: Herder, 1986, s. 214.

76 MAIER, Brief..., s. 117: „Es kann überdies keine Frage sein, dass für Jakobus das Gesetz, messianisch = 'christlich' ausgelegt, seine Verbindlichkeit auch im Neuen Bund behält."

77 Srov. Peter H. DAVIDS, The Epistle of James. A Commentary on the Greek Text, Grand Rapids, MI: Wm. B. Eerdmans Publishing Co., 1983, s. 114.

78 Frederick William DANKER, The Concise Greek-English Lexicon of the New Testament, Chicago and London: The University of Chicago Press, 2009, s. 350: „'bring to completion,' of functioning in a manner that leaves nothing undone.“

79 DANKER, Lexicon..., s. 350: „do (completely), of carrying out an action or objective to the fullest extent.“ 
přitom stojí aspekt jeho záměrné a vědomé praktické realizace, ${ }^{80}$ a proto lze v této souvislosti použít také překlad „uskutečňovat zákon“, nebo přesněji jeho požadavky. ${ }^{81} \mathrm{~V}$ Jakubově listě nelze

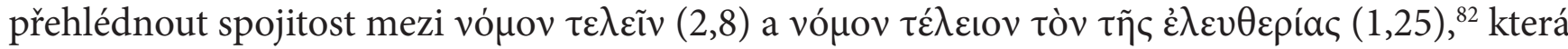
propojuje téma zákona s dokonalosti ${ }^{83}$ jako klíčovým tématem Jakubova listu. ${ }^{84}$ „Dokonalý zákon svobody“ $(1,25)$, který je Božím darem, provází věřící, kteří podle něj mají žít (

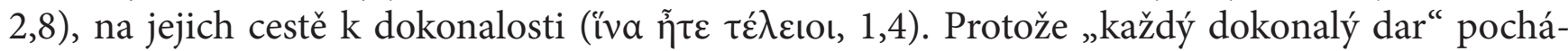

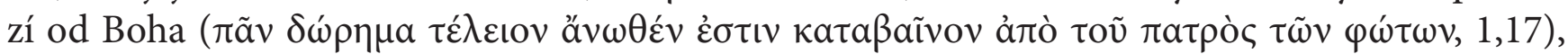
je dokonalost ve své finální podobě také darem Boha, který nakonec rozhoduje o definitivním

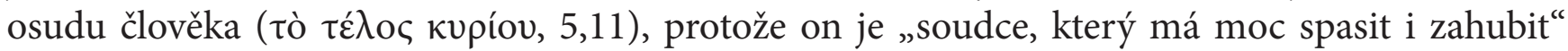

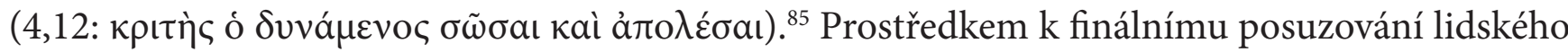
mluvení a jednání, je zákon svobody $(2,12)$. Atribut dokonalosti a atribut „královský“ související s Božím „královstvím“, které je stejně jako „věnec života“ přislíbeno „těm, kdo milují Boha“ (2,5; 1,12), tak potvrzují a doplňují tento eschatologický aspekt zákona.

\section{Ve shodě s Písmem}

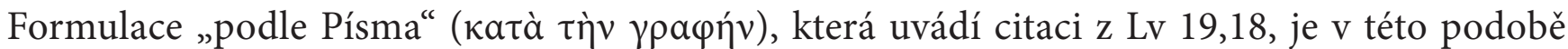
jediná v Novém zákoně. ${ }^{86} \mathrm{~V}$ Jakubově listě představuje velmi specifické uvedení přímé starozákonní citace, protože na všech ostatních místech $(2,11.23 ; 4,5.6)$ autor k tomuto účelu po-

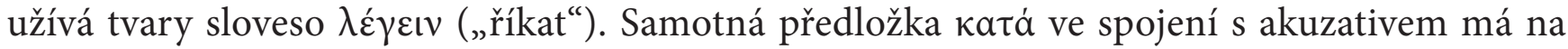

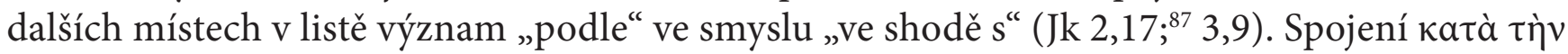

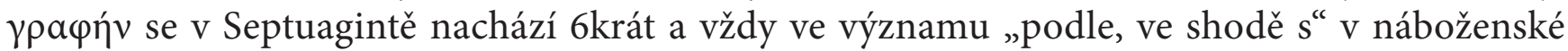
(Dt 10,4; 1 Pa 15,15; 2 Pa 30,5; Ezd 6,18) nebo politické souvislosti (2 Pa 35,4; 3 Ezd 1,4). Ani

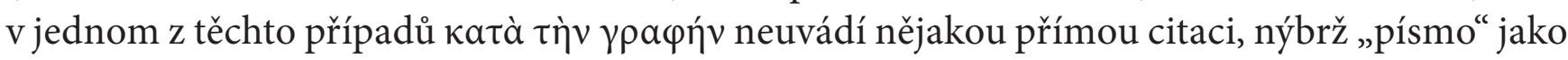
normu, podle které se něco musí vykonat. Lze se proto důvodně domnívat, že v tomto normativním smyslu použil uvedenou frázi také autor Jakubova listu: ${ }^{88}$ „jestliže naplňujete královský zákon ve shodě s tím, jak je uvedeno v Písmu“ ${ }^{89} \mathrm{~S}$ touto interpretací a s výše uvedeným tvrzením o nemožnosti ztotožnit přikázání lásky k bližnímu s „královským zákonem“ je spojena také

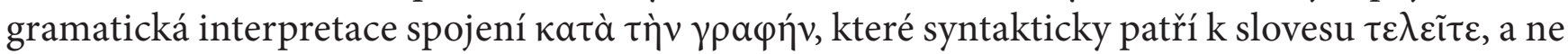

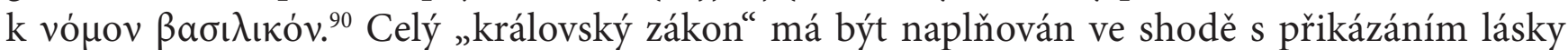
k bližnímu. ${ }^{91}$ To je sice také pouze jedním mezi ostatními starozákonními přikázáními, avšak

80 Arnold G. FRUCHTENBAUM, Der Jakobusbrief, Hünfeld: CMD, 2014, s. 65: „Das griechische Wort erfüllen bedeutet, etwas in die Praxis umzusetzen und das beabsichtige Ziel zu erreichen."

81 Walter BAUER, Griechisch-deutsches Wörterbuch zu den Schriften des Neuen Testaments und der frühchristlichen Literatur, 6. völlig neu bearbeitete Aufl. im Inst. für Neutestamentliche Textforschung, Münster, unter bes. Mitwirkung von V. Reichmann, hrsg. Kurt ALAND - Barbara ALAND, Berlin - New York: de Gruyter, 1988, sl. 1617: „die Forderungen des Gesetzes ausführen“.

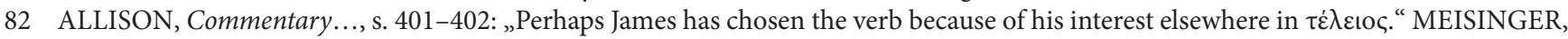

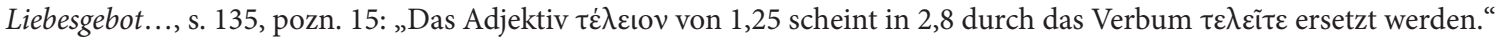

83 A nepřímo také s dalšími slovy s kořenem $\tau \varepsilon \lambda$-.

84 Ke vztahu zákona a dokonalosti viz více PAVELČíK, Zákon..., s. 185-190.

85 Srov. PAVELČÍK, Zákon..., s. 190.

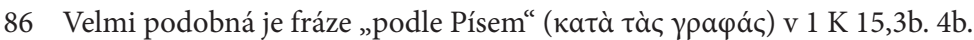

87 Zde se nejčastěji setkáváme s překladem „(víra) sama o soběc, avšak jak konstatují Jacqueline ASSAËL - Élian CUVILLIER, L’Épître de

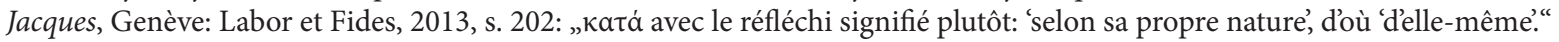

88 Srov. CHEUNG, Genre..., s. 99; THEISSEN, Nächstenliebe..., s. 135.

89 Srov. PAVELČíK, Zákon..., s. 202. Tento význam spojení „podle Písma“ v Jk podporuje také fráze „podle Písem“v 1 K 15,3b.4b, kde neuvádí žádný konkrétní citát ze Starého zákona, ale vyjadřuje, že Ježíšova smrt za naše hříchy a jeho vzkříšení byly v souladu se svědectvím Písem Starého zákona.

90 Srov. THEISSEN, Nächstenliebe..., s. 135; MEISINGER, Liebesgebot..., s. 136.

91 Srov. CHEUNG, Genre..., s. 99-100. 
se zvláštním postavením vůči nim, protože tato mají být uskutečňována podle něho.

Neobvyklé uvedení textu z Písma lze snad také vnímat jako jeden ze způsobů, jakým autor naznačuje toto jeho mimořádné postavení vzhledem k ostatním starozákonním prŕkazům a zá-

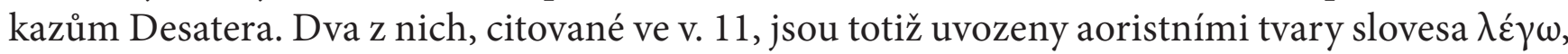
které ukazují na to, že se jedná o prosté citace, použité jako příklady organického propojení jednotlivých částí „celého Zákona“, spojeného ve v. 10 se slovesem „zachovávat“ ( listu prostřednictvím fráze „podle Písma“, propojením s „naplňováním královského zákona“ a komentářem „dobře činíte“ představuje přikázání lásky v jeho zásadní důležitosti a normativní funkci pro křest’any, ${ }^{93}$ pramenící z postavení a autority, které mu byly přisouzené v Ježíšově učení. ${ }^{94}$

Slova „podle Písma“ explicitně představují přikázání lásky jako normativní součást Písma, resp. Zákona, jak ukazují verše 8-11. Autor Jakubova listu (také) velmi pravděpodobně znal a vědomě použil starozákonní kontext tohoto přikázání z Lv 19,12-18. ${ }^{95} \mathrm{Zde}$, shodně jako na uvedeném místě Lv, je uvedeno ve spojitosti se zákazem stranění určitým osobám. Lv 19,15 v kontextu soudního sporu požaduje nestrannost jak vůči chudým, tak vůči mocným: „Neučiníte nespravedlnost $\mathrm{v}$ soudu; nebudeš stranit chudému ani nebudeš nadržovat mocnáři; spravedlivě

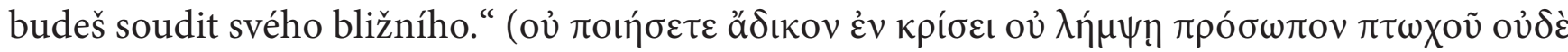

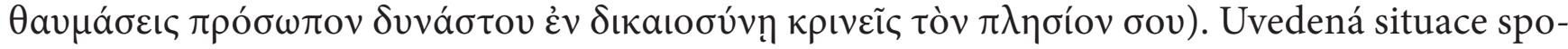
lu s charakteristikou a postavením „chudých“ ve druhé kapitole ( $\pi \tau \omega \chi \chi$ ó $2,2.3 .5 .6)$ neumožňuje Jakubovi převzít $\mathrm{z}$ Lv a apelovat také na nestranění chudým; jim straní sám Bůh, on je na jejich straně, a proto jim nelze nestranit. ${ }^{96}$ To by také mohl být jeden $\mathrm{z}$ důvodů, ${ }^{97}$ proč Lv 19,15 necituje explicitně. Ačkoli se v Jk 2,1-13 neřeší žádný konkrétní soudní případ jako v Lv 19, celá perikopa, ve které se nachází př́kazy nestranění a lásky k bližnímu, je protkaná soudní terminologií. ${ }^{98}$

Autor Jakubova listu tak velmi úzce propojil přikázání lásky k bližnímu a zákaz stranění společensky významnějším osobám podobným zpơsobem, jako je tomu v Lv 19,12-18. ${ }^{99}$ Přikázání lásky je podle něho tou určující normou, podle které má být dodržován a interpretován celý Mojžíšùv zákon, proto porušení zákazu stranění je také proviněním proti př́kazu lásky. ${ }^{100}$

92 KEITH, La citation..., s. 241-242: „Ces changements ne sont pas seulement l'expression d'un souci stylistique. Le verbe $\tau \varepsilon \lambda \varepsilon \dot{\varepsilon} \omega$ a une portée plus forte que le simple $\tau \eta \rho \varepsilon ́ \omega$ utilisé au v. 10 (...) En Jc 2,8, la 'Loi royale', la norme suprême et souveraine, est 'réalisée selon ce qui est écrit', et ce terme ( $\tau \varepsilon \lambda \dot{\varepsilon} \omega)$ est à comprendre au sens fort d'être portée à sa réalisation parfaite.““

93 Srov. KEITH, La citation..., s. 231 a 234.

94 LAWS, Commentary..., s. 110: „it is probable that when James quotes Lev. xix. 18 as scripture he does so in the knowledge that this scripture has received the added authority of Jesus' use."

95 Srov. JOHNSON, Use..., s. 399.

96 Jinak ale THEISSEN, Nächstenliebe..., s. 126: „Die Symmetrie der Unparteilichkeit in beide Richtungen ist eine der Pointe in Jak 2,1ff, auch wenn eine Begünstigung des Geringen, vor der in Lev 19,15 gewarnt wird, nicht im Blick ist.“

97 O dalších uvažuje např. THEISSEN, Nächstenliebe..., s. 129: „Vezichtet PsJakobus deshalb auf ein explizites Zitat von Lev 19,15, weil er das Gleichheitsgebot ganz eng mit dem Nächstenliebegebot verbinden will, um es so ins Zentrum des christlichen Ethos zu rücken? Will er sagen: Wer das Liebesgebot als Identitätsmerkmal der Christen ernst nimmt (was unumstritten ist), muss das Gleichheitsgebot ebenso ernst nehmen, da es die Kehrseite der Nächstenliebe ist?“

98 THEISSEN, Nächstenliebe..., s. 126-127: „Die Nächstenliebe wird im Jakobusbrief (wie in Lev 19) zwar eng mit forensischen Bildern verbunden, sie meinen hier aber metaphorisch das gegenwärtige ethische Urteil der Menschen, mythisch das zu erwartende Jüngste Gericht (Jak 2,12f). Forensisch ist vor allem das Gebot der Unparteilichkeit.“

99 Srov. také THEISSEN, Nächstenliebe..., s. 129-130.

100 Srov. JOHNSON, Use..., s. 400. 


\section{Milovat budeš svého bližního}

V Jakubově listě se kromě starozákonní citace z Lv 19,15 v 2,8 sloveso ả $\gamma a$ Tá $\omega$ vyskytuje už pouze 2 krát v 1,12 a 2,5 a jeho adjektivní derivát ả $\gamma a \pi \eta\rceil$ tó $3 k$ rát v 1,16.19 a 2,5. ${ }^{101}$ Význam obou termínů je spojen s láskou å $\gamma a \dot{\pi} \eta \eta,{ }^{102}$ která, podobně jako $\varphi \iota \lambda$ ía, označuje primárně , lásku, která vzniká na základě preferenci', avšak se specifickou nuancí „lásku, které můžeme svým rozhodnutím a rozumovou úvahou udat směr. Preference jsou tedy založeny méně na emocích a více na rozvaze. "103

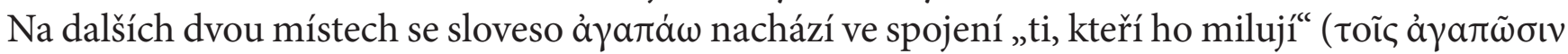
aủoóv), přičemž na základě kontextu „on“ v 2,5 je evidentně Bůh. V 1,12c podmět slovesa $\dot{\varepsilon} \pi \eta \gamma \gamma \varepsilon i ́ \lambda \alpha \tau o$ („přislíbil“) sice není vyjádřen explicitně, ale nelze vážně pochybovat o tom, že jím

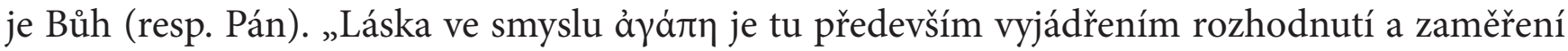
svého života, svojí osobnosti na Boha. " ${ }^{104}$ Kromě citace $\mathrm{z}$ Lv se další dva výskyty slovesa ả åááw vztahují na Boha. Ačkoli v Jakubově listě přikázání lásky $\mathrm{k}$ Bohu z Dt 6,5 není citováno, ${ }^{105}$ nelze popřít, že láska $\mathrm{k}$ bližnímu je pro jeho autora spojená s láskou $\mathrm{k}$ Bohu. ${ }^{106}$

„Ti, kteří milují Boha“ jsou ti, kteří žijí podle jeho zákona, ${ }^{107}$ jsou poslušní jeho zákona, a ne jeho soudci (srov. 4,11-12). V této souvislosti jsou pro nás instruktivní právě slova $\mathrm{z}$ veršů 2,5 a 1,12 o eschatologickém prríslibu království, resp. věnce života „těm, kteří milují Boha“. Slova toĩ à $\gamma a \pi \tilde{\omega} \sigma ı v$ aủtóv nápadně připomínají formulace z Desatera, ${ }^{108} \mathrm{kde}$ Bůh přislibuje své milosrden-

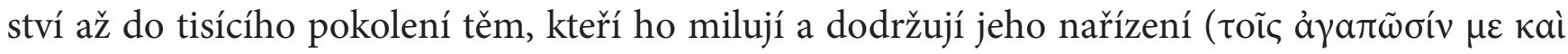

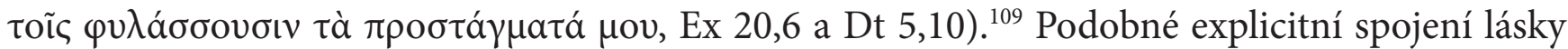
k Bohu s dodržováním jeho přikázání lze vidět i v Jakubově listě, kde jsou téměř bezprostředně vedle sebe výroky o království jako odměně pro ty, kdo milují Boha $(2,5)$, a o zachovávání královského zákona, resp. celého zákona $(2,8.10)$.

Z některých míst Jakubova listu lze vyčíst, jakým způsobem se podle něj konkrétněji projevuje nebo má projevovat láska $\mathrm{k}$ Bohu. „Ti, kteří milují Boha“ jsou ti, kteří ho žádají správně (srov.

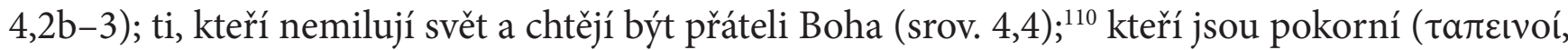
4,6), podrobují se Bohu (srov. 4,7), přibližují se k němu s čistýma rukama a čistým srdcem $(4,8)$, pokořují se před Pánem, protože pouze On je může povýšit $(4,10)$. Opak toho všeho rozvrací společenství, způsobuje rozbroje, závist, resp. žárlivost, ${ }^{111}$ boje uvnitř společenství $(4,1-2)$, za kterými stojí „utápění se v žádostivostech a rozkoších (srov. 4,1b.3b). Jsou to také ti, kteří jsou aktivními př́ijemci a vykonavateli spásonosného slova $(1,22.21)$, jímž je Bůh z rozhodnutí své vưle zrodil, aby životem ve svobodě Božích stvoření $(1,18)$ směřovali ke spáse. „,Konání slova je odpovědí na

$101 \mathrm{Z}$ termínů pro „lásku“ se zde nachází ještě $\varphi \imath \lambda i ́ a(4,4)$ a s ní související substantivum $\varphi$ í̉oৎ $(2,23 ; 4,4)$.

102 Toto substantivum se však v Jk nenachází.

103 Veronika ČERNUŠKOVÁ, Tři stupně lásky v řeckém jazyce? Výrazy „milovat“ a „láska“ v klasické řecké literatuře a u církevních otců, Studia Theologica 1/2014, s. 27. LOH - HATTON, A Handbook..., s. 73: „In this context the ideas of duty or loyalty are foremost, rarther than the meaning 'like someone very much."

104 ŠTRBA, Emócie..., s. 247.

105 Což nepřekvapuje, protože př́má citace Dt 6,5 se v Novém zákoně nachází pouze u synoptiků: Mk 12,30.33; Mt 22,37; L 10,27.

106 Viz Ralph P. MARTIN, James, Waco, Texas: Word Books, 1988, s. 69. HOPPE, Hintergrund..., s. 89: „Zusammen mit dem Gebot zur Nächstenliebe 2,8 kennt der Jak auch die Liebe zu Gott, vgl. 1,12; 2,5; gerade in diesen beiden Motiven realisiert sich das 2,1 geforderte

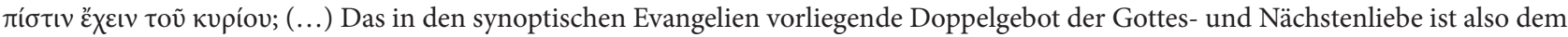
Jak, wenn auch nicht in der Zusammenstellung, durchaus bekannt."

107 JACKSON-MCCABE, Logos..., s. 166: „Love of God, while not, to my knowledge, explicitly cited as a summary of the law, is routinely used in Jewish literature as a shorthand expression for living in accord with the law."

108 JACKSON-MCCABE, Logos..., s. 166.

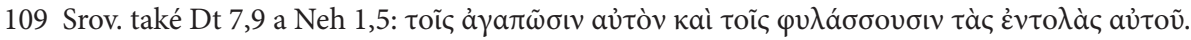

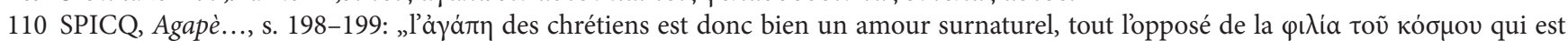
inimitié à l'égard de Dieu $(\mathrm{IV}, 4)^{\text {“c. }}$

111 Viz ŠTRBA, Emócie..., s. 256-259. 
to, co Bůh zamýšlel s člověkem, když do něho ,slovo ,zasadil." "112 Jsou to ti, kteří před Bohem projevují „čistou a neposkvrněnou zbožnost“ tím, že „navštěvují siroty a vdovy v jejich soužení a sebe zachovávají neposkvrněnými od světa" $(1,27)$. Ti, kteří nežehnají pouze Pána a Otce, ale i ostatní lidi $(3,9),{ }^{113}$ nepomlouvají bratra a nesoudí bližního $(4,11-12)$. Ti, kteří ve svém životě, v plánování své budoucnosti berou zcela vážně Boha jako Pána nad svým životem $(4,15)$. Ti, kteří trpělivě čekají na př́íchod Pána (srov. 5,7-11) a v jakékoli situaci se na něho obracejí v modlitbě $(5,13)$.

Ve verších 2,19 a 4,12, v nichž se mluví o jedinosti Boha, Zákonodárce a Soudce, lze rozpoznat ozvěny Dt 6,4-5, kde je víra $v$ jediného Boha neoddělitelně spojena s naprostou oddaností a lás-

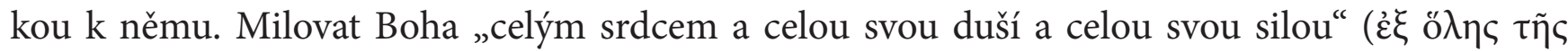

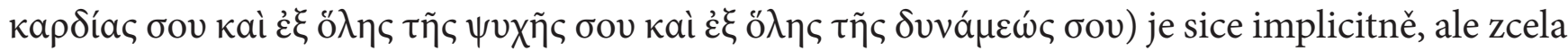
př́mo v protikladu s postojem adresátů listu, kteří jsou ve svém vztahu k Bohu rozpolceni, což

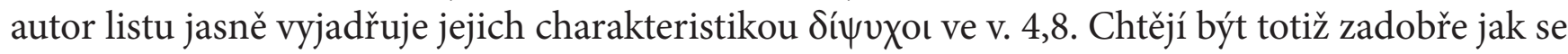
světem, tak i s Bohem (viz 4,4). ${ }^{114}$ Rozpolcenost ve vztahu k Bohu se promítá i do vzájemných mezilidských vztahů uvnitř společenství (viz např. 2,2-4.14-16; 3,14-16;4,1-2.11; 5,4.9), což jen potvrzuje naléhavost usměrňovat je životem podle Zákona ve shodě s přikázáním lásky k bližnímu.

Stejně jako na všech ostatních místech Nového zákona, kde se cituje přikázání lásky k bližnímu z Lv 19,18, s výjimkou Lukášova evangelia (srov. L 10,29.36), ani autor Jakubova listu blíže neobjasňuje, kdo má být považován za bližního. Ve svém spise termín $\pi \lambda$ ¡oiov kromě 2,8 používá ještě v 4,12, v kontextech do jisté míry př́ibuzných. ${ }^{115}$ Perikopy $2,8-13$ a 4,11-12 jsou si blízké na

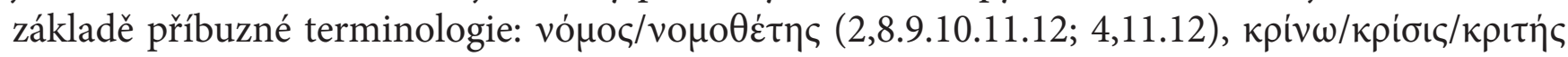
$\left(2,12.13 ;^{116} 4,11.12\right), \pi \lambda \eta \sigma i o v(2,8 ; 4,12)$. V obou př́padech je tato terminologie zákona a soudu použita ve spojitosti s jistým konkrétním jednáním ve společenství adresátů: s nadržováním osobám, resp. s osočováním bratra. Protože ve 4,11-12 autor zcela plynule přechází od použití „bra-

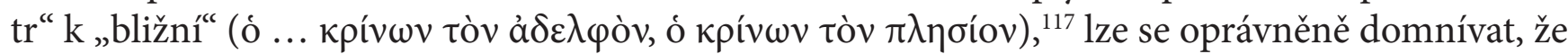
obsahy obou termínů se pro něho do značné míry překrývají. Na podobné sémantické překrytí lze usuzovat také v oddílu 2,8-11(13), kde stejně jako v 4,11-12 jsou adresáti oslovováni jako „bratři““ (srov. 2,1.5; viz také 2,14), jimž je adresována starozákonní citace př́íkazu lásky k bližnímu v 2,8. ${ }^{118}$

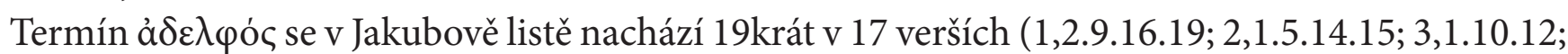
4,11 [3krát]; 5,7.9.10.12.19), ${ }^{119}$ prričemž autor ho $15 \mathrm{krát}$ používá ve tvaru vokativu plurálu k oslovení adresátů. Lze tedy konstatovat, že se jednoznačně aplikuje a vztahuje na členy věřícího spo-

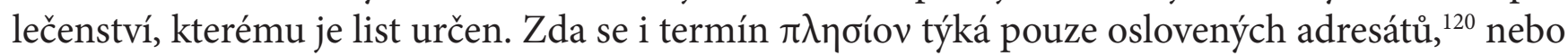

112 PAVELČÍK, Zákon..., s. 184.

113 HOPPE, Hintergrund..., 89: „wenn der Verfasser kritisiert, daß die Hörer mit demselben Mund Gott loben und der Mitmenschen verfluchen, 3,9f., dann steht dahinter der Gedanke, daß Gottes- und Nächstenliebe sich nicht widersprechen dürfen."

114 Srov. Richard BAUCKHAM, James. Wisdom of James, disciple of Jesus the sage, London and New York: Routledge, 1999 , s. 145.

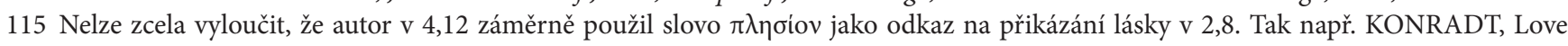
Command..., s. 280-281; CHEUNG, Genre..., s. 122.

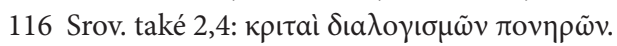

117 THEISSEN, Nächstenliebe..., s. 136: „'Bruder' begegnet hier, weil von einem zwischenmenschlichen Verhältnis auf Gegenseitigkeit die Rede ist - von Menschen, die sich gegenseitig herabsetzen können (4,11). 'Nächster' begegnet in dem Augenblick, in dem vom Verhältnis zu Gott die Rede ist - als dem Richter, 'der die Macht hat, zu retten und zu verderben' $(4,12)$.“

118 Vidíme, že autor listu se termínu $\pi \lambda$ qoíov nevyhýbá, nesnaží se být důsledný v používání pouze termínu „bratr/bratřii“, podobně jako je tomu v Prvním listě Janově, kde se slovo $\pi \lambda$ q $\sigma$ iov vůbec nenachází. Obdobně je tomu i v Janově evangeliu, kde se slovo $\pi \lambda \eta \sigma i o v$ nachází pouze jednou $(4,5)$ ve významu předložky s významem „nedaleko, blízko“. K významu tohoto slova viz TICHÝ, Slovník..., s. 139.

119 Tvar ženského rodu ả $\delta \varepsilon \lambda \varphi \eta ́$ pouze jednou v 2,15.

120 V rámci specifické situace vylíčené v 2,1-7 lze zcela oprávněně uvažovat o tom, že autor pod „bližním“ má na mysli hlavně „chudého“ ( $\pi \tau \omega \chi o ́ \varsigma)$. Tak např. Peter WICK, Zwischen Parteilichkeit und Barmherzigkeit! Jak 2,1-13 und die elaborierte Ethik des Jakobusbriefes, 
má být chápán $\mathrm{v}$ širším, univerzalistickém rozsahu, ${ }^{121}$ nelze na základě pouhých dvou výskytů jednoznačně rozhodnout, zvlášt když $v$ jednom př́padě se jedná o převzatou starozákonní citaci a ve druhém tento pojem plynule alternuje s termínem ả $\delta \varepsilon \lambda \varphi o ́ c .{ }^{122}$ Oba kontexty však shodně vyjevují a potvrzují, že vztah k bližnímu je zásadním způsobem určován a spojen s podřízením se zákonu, uznáním jeho autority, za kterou stojí sám Bůh. ${ }^{123}$

\section{Dobře činíte}

Pokud adresáti listu naplňují královský zákon ve shodě s přikázáním lásky, činí dobře ( $\kappa a \lambda \tilde{\omega} \varsigma$

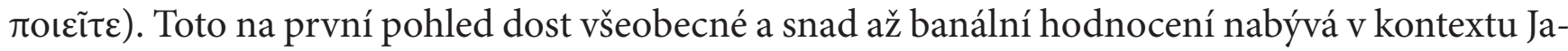

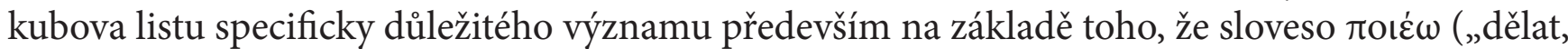
činit, konat" apod.) ${ }^{124}$ se v něm nachází $12 \mathrm{krát} v$ různých, většinou teologicky relevantních souvislostech $(2,8.12 .13 .19 ; 3,12$ [2krát].18; 4,13.15.17[2krát]; 5,15), $\mathrm{k}$ tomu navíc podstatné jméno

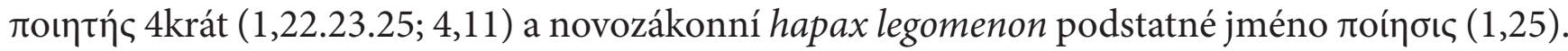

Ve verších 2,12-13 je sloveso $\pi$ olé $\omega$ uvedeno ve spojitosti se soudem: lidské mluvení a lidská

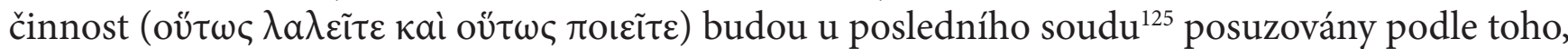

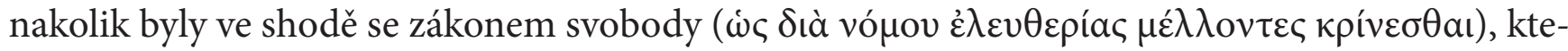
rý je rozhodujícím prostředkem souzení v rukou samotného Boha, jediného Soudce (srov. 4,12). Uskutečňování požadavků zákona svobody nelze podle 2,13 oddělit ( $\gamma a ́ \rho)$ od prokazování milo-

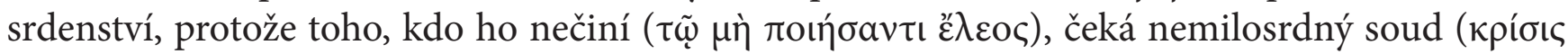

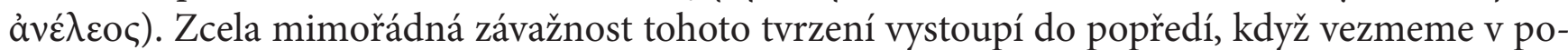

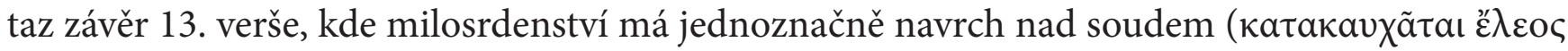

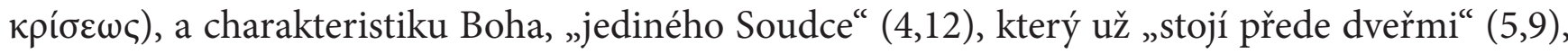

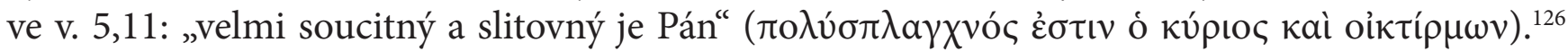
Nekonečná velikost Božího milosrdenství, které je jeho bytostní charakteristikou a vlastností, je limitována (sit venia verbo) neochotou a neschopností člověka projevit milosrdenství druhému. Protože není schopen jednat s druhými milosrdně, není schopen přijmout Boží milosrdenství, ${ }^{127}$ sám sebe vylučuje $z$ jeho dosahu. Jak už bylo uvedeno výše, tematika zákona v 2,8-13 je orámovaná přikázáním lásky k bližnímu ve v. 8 a milosrdenstvím ve v. 13. Projevování milosrdenství tak je, resp. má být jedním z podstatných charakteristických projevů života věŕícího společenství, které naplňuje požadavky zákona ve shodě s přikázáním lásky k bližnímu. Verše 2,12-13, podobně jako 1,25 , velmi jasně ukazují na eschatologické důsledky př́tomného jednání.

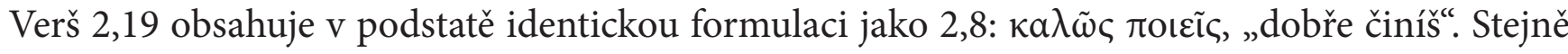
jako naplňování královského zákona ve shodě s přikázáním lásky k bližnímu je i víra v jediného

Annali di storia dell' esegesi 2/2017, s. 450. Na druhou stranu však ani v Jk nelze redukovat „bližního“ pouze na „chudého“.

121 Názor, který zastává zejména Gerd Theißen ve svém článku Nächstenliebe und Egalität (viz pozn. 35).

122 ALLISON, Commentary..., s. 406: „The inner-Jewish debate over how expansively to understand 'neighbor' seems irrelevant for understanding James if all the parties concerned belong to the same synagogue (vv. 1-7).“

123 Srov. CHEUNG, Genre..., s. 123.

124 Srov. TICHÝ, Slovník..., s. 139.

125 Cain H. FELDER, Partiality and God's Law: An Exegesis of James 2:1-13, The Journal of Religious Thought 2/1982-1983, s. 51-69, s. 68: "If James does consider God to be the authoritative judge, then presumably James represents an imminent eschatological metaphor in 5:9c („the judge stands at the door“) in which the final judgment has God as the central figure. (...) When James 2:13a is considered in

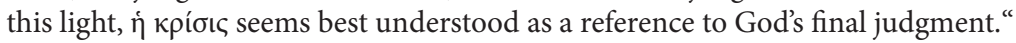

126 Podrobněji k tomuto viz článek Július PAVELČÍK, „Velmi súcitný a lútostivý je Pán“ (Jak 5,11): K jednému aspektu Boha v Jakubovom liste, Studia Biblica Slovaca 1/2016, s. 65-87.

127 Frank STAGG, Exegetical Themes in James 1 and 2, Review and Expositor 4/1969, s. 400: „To lock another out is to lock oneself in. To reject mercy for other is to reject mercy for oneself." 


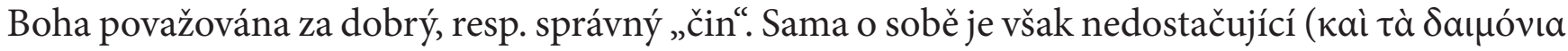
$\pi ı \sigma \tau \varepsilon v 0 v \sigma ı v$ kaì $\varphi \rho i ́ \sigma \sigma o v \sigma ı)$, a pokud není doprovázena a dovršována skutky, jak ukazuje př́í-

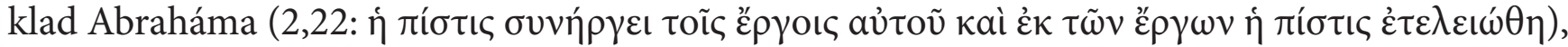

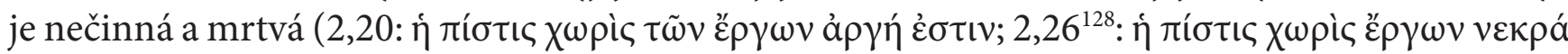

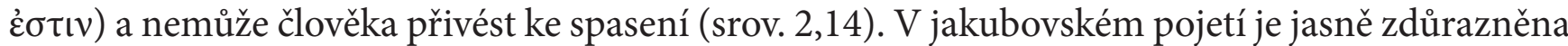
soteriologická relevance konkrétního lidského jednání, které je projevem a důkazem životaschopnosti víry v Ježíše Krista (srov. 2,1).

Obrazem použitým v 3,12 autor listu formou řečnické otázky názorně demonstruje jistou nepřirozenost dvojího používání jazyka. Jako fíkovník nemůže dávat (dosl. „činit“) olivy a vinná réva fíky a slaný pramen nemůže produkovat (dosl. „činit“) sladkou vodu, ${ }^{129}$ tak je nežádoucí a nepřijatelné, aby člověk týmž jazykem žehnal Bohu a zároveň proklínal člověka stvořeného podle po-

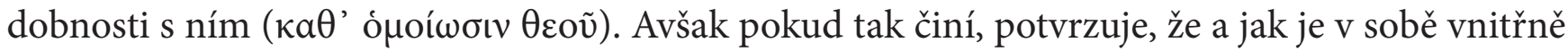
rozpolcen $(1,8: a ̉ v \eta ̀ \rho ~ \delta ́ 千 v \chi \chi \varsigma)$ ve vztahu $\mathrm{k}$ Bohu, stejně jako je ve vztahu k němu rozpolceno také

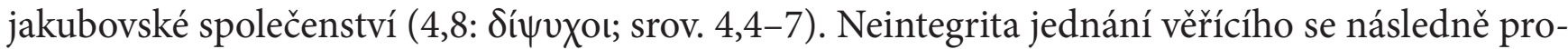
jevuje také ve dvojakosti jeho mluvení.

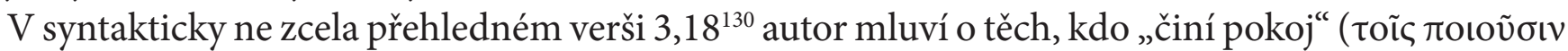

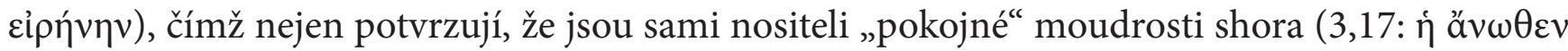

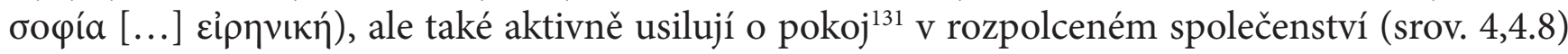

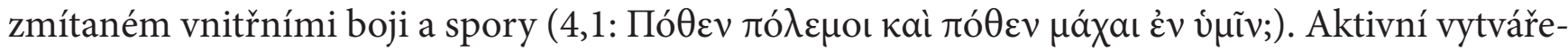
ní pokoje tak má zásadní ekleziologické důsledky pro živoucí a praktickou integritu společenství věŕících.

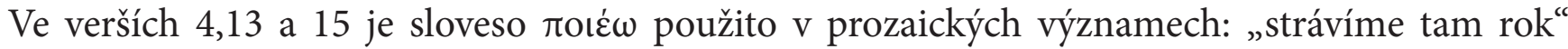
( veršů 4,13-16 autor listu ukazuje na to, že žádná lidská činnost, obzvlášt ta, která se týká plánová-

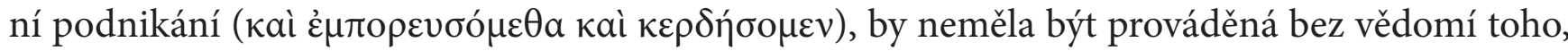

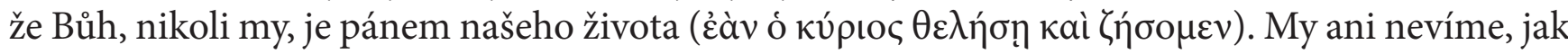
bude vypadat náš zítřejší den, a sami jsme jen „mlha“, která se zakrátko rozplyne $(3,14)$. Lidská činnost je prostě existenčně závislá na Boží vưli.

Jako „prvotina tvorü“ zrozená „slovem pravdy“ z rozhodnutí Boží vůle $(1,18)$ jsou věřící kromě jiného povoláni k tomu, aby svou pokornou moudrost dosvědčovali skutky svého „dobrého živo-

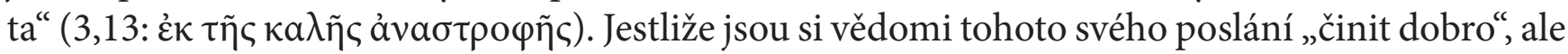

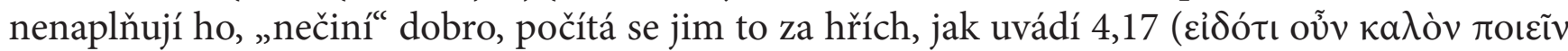

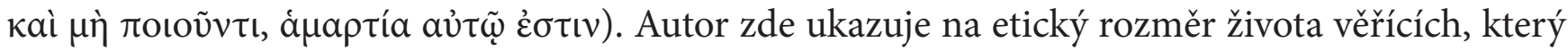
s sebou nese závazek konat dobro ve shodě s Boží vưlí. Hř́išné jednání má totiž závažné negativní soteriologické důsledky.

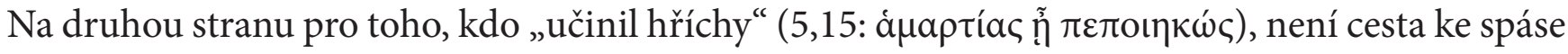
definitivně uzavřena. Podle Jakubova listu totiž uvnitř společenství adresátů lze dosáhnout odpuštění hříchů, pokud si je vzájemně vyznávají a navzájem se za sebe modlí $(5,16)$, protože modlitba víry má spásný potenciál $(5,15) .{ }^{132}$ Každý ze společenství by měl usilovat o obrácení hříšníka

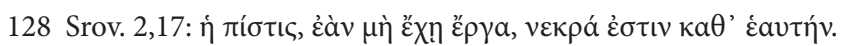

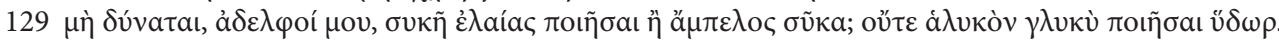

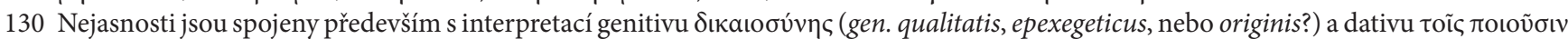
(dat. commodi, nebo auctoris?). Viz pojednání napr. v METZNER, Brief..., s. 209-211; ALLISON, Commentary..., s. 584-587.

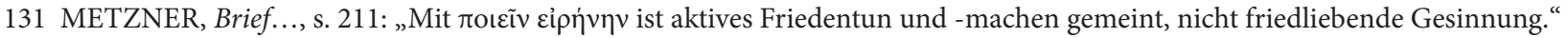

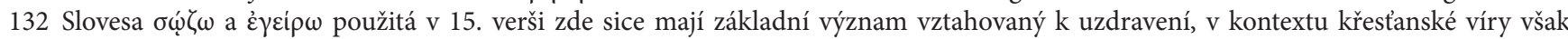
ukazují také na aspekt soteriologický a eschatologický, kdy je uzdravení vnímáno jako zkušenost s Boží mocí, která křísí mrtvé a kterou společenství už nyní zakouší jako jakousi anticipaci eschatologické obnovy celého stvoření. 
z jeho klamné cesty, které zakryje množství jeho hříchů a zachrání ho před smrtí $(5,20)$.

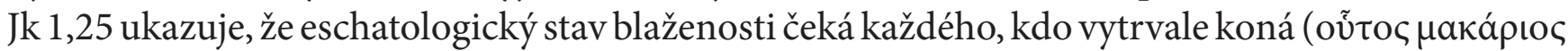

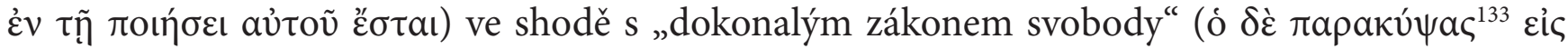

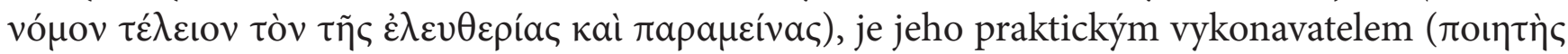

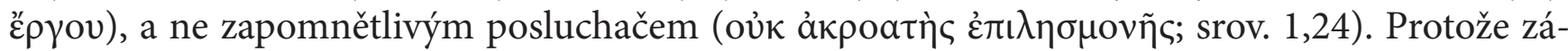
kon podle autora listu představuje imperativní a zavazující aspekt „slova“, ${ }^{134}$ být „vykonavatelem

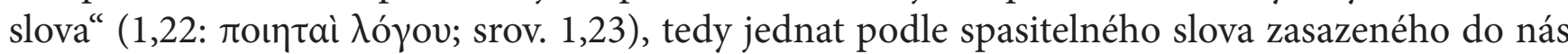

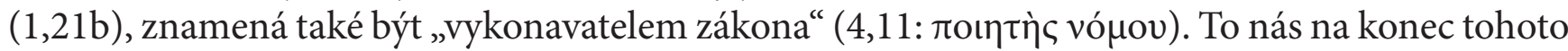
přehledu $\mathrm{o}$ „činění/jednání $v$ Jakubově listě přivádí k pojednávanému verši 2,8 , kde je jako dobré jednání $(\kappa a \lambda \tilde{\omega} \varsigma \pi \circ \varepsilon \varepsilon i \tau \varepsilon)^{135}$ hodnoceno to, které realizuje královský zákon ve shodě s přikázáním lásky k bližnímu.

\section{Závěr}

Ambivalentní vztah jakubovského společenství k Bohu, které je ochotno podřídit se také „světu“, jeho hodnotám a normám a jeho morálce (srov. 4,1-10), se odráží i v jeho nedůsledné praktické realizaci přikázání lásky k bližnímu, což se podle autora listu zvláštním způsobem projevuje ve stranění bohatým. Tím se také proviňuje proti zákonu, který je ve svém celku nositelem královské, tedy nejvy̌šší důstojnosti, a má královskou, tedy rozhodující a definitivní platnost v „prostoru“ Božího království. Je normou stanovenou „jediným Zákonodárcem“ $(4,12)$, kterou se má řídit veškerý život věŕícího společenství. Hlavním ukazatelem v tomto je pro ně starozákonní přikázání lásky k bližnímu (Lv 19,18), jak ukazuje jeho uvozující formule „naplňovat královský zákon podle Písma" v 2,8. Láska k bližnímu, i když ne explicitně, je také v Jakubově listě neoddělitelně spojena s láskou $\mathrm{k}$ Bohu. Termín „bližní se v kontextu celého spisu vztahuje na všechny věŕící společenství adresátů, přičemž však nelze zcela vyloučit ani jeho širší pojetí přesahující hranice tohoto společenství.

V kontextu nesporného důrazu na praktický rozměr křestanské víry, potvrzený jak výše uvedenými poznámkami, tak také známou perikopou 2,14-26 o vztahu víry a skutků, lze konstatovat, že láska v pojetí Jakubova listu má, resp. má mít především charakter aktivního etického jednání zaměřeného ekleziologicky k budování společenství, soteriologicky ke spáse vlastní i ostatních a eschatologicky k obstání u posledního soudu, při kterém sehrává rozhodující roli zákon, jehož konkrétní realizace je určována a zároveň posuzována podle lásky k bližnímu. Zákon v jakubovském pojetí není jakousi abstraktní či amorfní veličinou, ale v židokřestanském prostředí listu zahrnuje všechna přikázání Tóry ${ }^{136}$ interpretovaná v kontextu víry v Ježíše Krista se zvláštním ohledem na přikázání lásky a milosrdenství jako rozhodující principy jednání. V užším kontextu veršů 2,1-13 je láska k bližnímu představena jako základ stejného jednání vůči chudým a bohatým. Nadržuje-li společenství bohatým osobám, řídí se jinými principy než principem lásky a je usvědčeno $z$ přestoupení královského zákona tím samým zákonem, který lásku požaduje. ${ }^{137}$

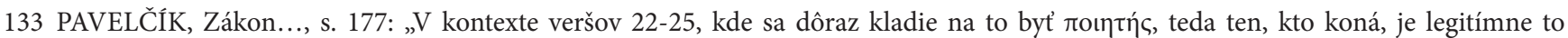

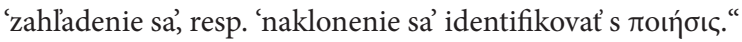

134 Srov. výše s. 149.

135 HOPPE, Hintergrund..., s. 97: „Voraussetzung zu solchem Handeln ist nach unserem Abschnitt das Erfüllen des ganzen Gesetzes, oder, um noch einmal auf 1,25 zurückzukommen, das Beharren im 'vollkommenen Gesetz."

136 Jakubovské pojetí zákona není omezeno pouze na Dekalog, ale zahrnuje také etická přikázání Tóry a nelze z něho zcela vyloučit ani její rituální předpisy. Více k tomuto viz PAVELČÍK, Zákon..., s. 205-206; PAVELČÍK, Nábožnosț..., s. 25-26.

137 Srov. Dmitri ROYSTER, The Epistle of St. James: A Commentary, Yonkers, NY: St Vladimir’s Seminary Press, 2010, s. 50. 
caritas

\section{Kontakt}

Thlic. Julius Pavelčík, Th.D.

Jihočeská univerzita v Českých Budějovicích

Teologická fakulta

Katedra teologických věd

Kněžská 8, 37001 České Budějovice

pavelcik@tf.jcu.cz 